\title{
WILDERNESS - CONSEQUENCES OF A MENTAL CONSTRUCT FOR LANDSCAPES, BIODIVERSITY AND WILDERNESS MANAGEMENT
}

\author{
GERD LUPP \\ Leibniz Institute of Ecological Urban and Regional Development, Weberplatz 1, 01217 Dresden, Germany. Tel.: +49-351-4679-279 \\ Corresponding author: g.lupp@ioer.de, luppg@gmx.de
}

\begin{abstract}
The paper discusses the concept of wilderness as a strategy for protecting biodiversity and as one of the key goals in environmental policy. It discusses the dimensions and consequences of the strategies of rewildering stretching from large land abandonments down to urban wasteland. The paper analyses the consequences and effects of land use abandonment and management strategies towards more naturalness and wilderness. A second focus is also laid on the social dimension of wilderness, the attempts of defining wilderness by spatial extents or features as well as its perception by laypersons. It is pointed out that wilderness has a strong mental component related with feelings like solitude and nature experiences.
\end{abstract}

Keywords: wilderness, biodiversity, landscape perception, Central Europe

\section{Wilderness - From the edge of survival to the heart of capital cities}

One of the core challenges at international, national and regional levels is maintaining biodiversity. The Federal Cabinet adopted the establishment of wilderness in urban and rural areas in November 2007 as one of the key strategies in the German National Strategy on Biological Diversity (BMU 2007). The main objective was to secure $2 \%$ of the country's land cover as wilderness. These areas are considered to provide nature experiences for visitors (BMU 2007). Larger areas should serve as a core for regional development of the surrounding areas (Nationalparkamt Müritz 2003).

Although there is no clear definition of wilderness in the German National Strategy on Biological Diversity (Lupp et al. 2011), landscapes classified as "wilderness" adopt the description proposed by Kowarik (2005). In his paper he describes four dimensions of "wilderness" comprising two categories, "traditional" and "new" wilderness. The classification "remnants of virgin forests" in the "traditional wilderness" category hardly exists in central Europe. Therefore, one of the core strategies to provide wilderness areas in Central Europe is to develop large national parks that meet the criteria set out in the internationally recognized IUCN category II standards. In most places in Central Europe, land has been intensively used for centuries, and landscapes, habitats and species composition have been altered by human activities. Even in very remote areas far away from settlements, vegetation patterns are modified by the grazing of domestic animals, and the harvesting of fodder or extraction of timber. To reach IUCN category II standards, a lot of restoration activities such as regeneration of wetlands, active manage- ment or natural processes to transform planted conifer stands have to take place to reach these goals.

The category "new wilderness" comprises land use abandonment in peripherical regions that have arisen as a result of structural changes in agriculture and society. Changes to the urban landscape brought on by intensive competition for space for additional commercial or residential development often results in the generation of waste lands, brown field sites and "decommissioned" facilities and infrastructures that are no longer needed or are too cost-intensive to adapt (Brückner et al. 2007). This leads to long-term unused or abandoned areas ranging from several hundred square meters to more than 10,000 ha (Kowarik 2005) in size. This "abandonment" of unutilized land is considered by the German national biodiversity strategy to be an opportunity to establish "islets" of wilderness even in urbanized areas. One good example for "new wilderness" is the former railway shifting yard of Berlin Südgelände, abandoned in 1945 and unmanaged since then. As a consequence, this site remained undisturbed for a longer period than for many of the designated core zones within the German national parks. Finally, there is a category "nature experience wilderness" with an emphasis on nature experience and environmental education, where images of wilderness are created artificially by landscape design. However, the question arises, what happens in these "wilderness areas" and are these landscapes really perceived by the public as wilderness areas.

\section{Does Biodiversity need Wilderness?}

Published reviews on the topic of wilderness that address the four dimensions described by Kowarik (2005), 
conclude that conservation strategies that embrace the wilderness concept do not necessarily increase species richness, at least in the short and medium terms. Anthropogenic ecosystems such as meadows or even military firing ranges may contain more species than unmanaged wilderness plots (Gärtner et al. 2009). Management release allows succession to take hold of previously open habitats. As a result, the structural diversity of the landscape changes and the floristic species richness decreases significantly from lower to higher successional stages (e.g. Höchtl et al 2005 for landscapes in the Southern Alps). Kowarik (2008) shows that vegetation composition on abandoned urban brownfields is often dominated by non-native species that out-compete native species, especially in the tree layer. On the other hand, studies have found a number of Red List species on these same sites (e.g. Keil et al. 2002; Junghans 2007). Large unmanaged landscapes and large-scale land use abandonment provide top predators like wolves (Canis lupus) suitable habitats with few conflicts arising from land uses like animal husbandry. However, these wild species are not necessarily dependent on land use abandonment or unmanaged landscapes, and they may be able to survive in managed cultural landscapes as well (Okarma and Langwald 2002). Wilderness, therefore, is not be defined by spatial extents of large carnivore habitats only and ultimately it is just one of several conservation strategies.

\section{The Müritz National Park Case Study: Management towards wilderness and its impact on landscapes}

At the landscape level, a study in Müritz National Park (Lupp et al. in press) tried to analyze future impacts for the Müritz National Park. According to the results presented in this study, the predicted findings for studies carried out among key stakeholders for agricultural land, indicate that some changes would be immediately noticeable, especially those affecting the lakes as the most important visual landscape element to the visitors of the park (Lupp and Konold 2008). Fallow land would increase while the amount of cultivated fields would diminish. Also some spontaneous reforestation is likely to occur in the coming years, but not on a very large scale. Sites along water courses and lakes that are difficult to maintain would most likely be affected. One of the main reasons for this predicted development is the priority of farming activities and the lack of regulation to restrict cultivation practices. Planning and even dedicating their land as a national park has limited effects on the remaining farming activities inside the park boundaries. This can be attributed to the fact that agriculture is prioritised to a large extent.

Only marginal changes will be visible in the forthcoming years in the national park forests, as they are a generally slow-reacting ecosystem. At present, $72 \%$ of the forests are dominated by pine. Many stands can be characterized as young, planted, even-aged stands that were shaped by intensive forestry during the socialist era before 1990. Most of the stands at that time were clearcut once the trees reached 110 years, and then replanted with pines (Pestel and Schäfer 1991). To change the pine forests towards more natural stands, management plans prescribe thinning in younger stands to allow the growth of beech and oak. Although testing different management options for these stands, Lupp et al. (in press) have suggested that pine will dominate in the coming decades, and it will take a minimum of 20-30 years before beech is re-established in these stands and the aesthetic character of the forest is altered. Strict IUCN guidelines will lead to the gradual phasing out of forest management actions in many areas in the national park, which are legally mandated for the largely public-owned forests inside the park boundaries. The crucial point is to consider the amount of beech and oak available to provide seed for natural broadleaf regeneration in pine stands. Therefore, effects of the proposed management actions seem to be limited to the overall visual appearance of the forest.

\section{Wilderness - A mental construct}

Lupp et al. (2011) point out that attempts to define wilderness by experts are often underpinned by ethical, religious, educational and cultural motives, and reflect more romantic notions of nature than exists in reality (Nash 2001), a "mental construct" (Vincenzotti and Trepl 2009) or a personal feeling (Stremlow and Sidler 2002). In consequence, even vegetation in a crack in the pavement or a bird singing in the city might be considered "wilderness" for a human (Brouns 2004). Lupp et al. (2011) conclude that "wilderness" is not subject to purely rational definitions and often has a strong emotional connection with nature. Nevertheless, the term "wilderness" is broadly used and especially for national parks, it is understood to be a means of allowing natural dynamics without human interference (e.g. Nationalparkamt Müritz 2003; Nationalparkverwaltung Bayerischer Wald 2009).

The German nationwide study for nature protection awareness shows very high acceptance rates for the goals set in the biodiversity strategy among all groups of society (UBA 2009). However, wilderness aspects were not explicitly assessed prior to this study. A number of user-based studies have been carried out in recent years in Central Europe dealing with biodiversity conservation, wilderness and importance of wilderness (e.g. Hunziker 1995; Hunziker 2000; Wasem 2002; Höchtl et al. 2005; Bauer et al. 2009). Natural dynamics and protecting biodiversity as key elements of wilderness and re-wildering are seen as a positive development. However, the consequences of an unhindered landscape development were mainly perceived negatively, mainly a loss of identity for 
local people and disappearing elements of traditional rural landscape elements like wine yards, fruit orchards and flowering meadows (e.g. Höchtl et al. 2005).

The perception of shrub and woodland on abandoned urban and industrial sites has been investigated in studies that have carried out focus-group interviews (Breuste and Breuste 2001; Rink 2002; Schemel et al. 2005; Keil 2005; Hohn et al. 2007). In Eastern Germany, research findings indicated that public perception of urban wilderness was largely negative and associated with "danger", and connected with economic collapse (Rink 2003). Studies by Keil (2005) and Schemel et al. (2005) in the Ruhr Region point out that the aesthetic quality attached to features of urban wilderness was also low. However, these same features were perceived to have some value for recreation, nature protection and environmental education. Mathey and Rink (2009) summarize that urban wilderness is not perceived as such by users or different interest groups and generally does not exist in the urban domain.

Important features of "wilderness", according to the results of a public survey on attitudes to wilderness, identify a number of diagnostic characteristics including solitude, little visible human interference and other features such as "impassable", bogs, wetlands and vast forests (Lupp et al. 2011). Müritz National Park had many of these features according to the interviewees, and an above average number (58\%) of respondents perceived it as a wilderness area. The scenic quality of mature unmanaged beech forests in the Serrahn Part of the park is considered to be high according to the results of both on-site interviews and picture set ranking. Deadwood in these forests, at least to some extent, is seen as an explicit positive feature. However, background information is important for judging whether scenic qualities are considered positive or negative, especially for less common situations such as regenerating wetlands with their abundant deadwood.

To a lesser extent, high-value semi-natural grasslands, reed beds and fields in the Müritz National Park are viewed as part of wilderness although these habitats will be managed in the future. In these areas, the overall appearance of fields has changed, since many of them have become fallow. In general, fallow land is considered less attractive. However, it is often not identified as such in landscapes, since it has many different qualities and diverse aspects even throughout one year (Lupp and Konold 2008). It also might be associated with urban brownfields and with the decline of the economy. Therefore it is negatively perceived, especially among the local people, and is not necessarily related to real scenic qualities.

\section{Conclusions}

At the landscape level, new, unmanaged land use types are emerging in Central Europe. At species level, wilderness as a strategy for biodiversity might, on the one hand, lead to a loss of species compared to previous land uses, especially compared to extensively utilized cultivated land. On the other hand, new types of emergent vegetation types appear, often dominated by non-native species, which suppress and eliminate native ones on these sites. However, the extinction of native species is in many cases not due solely to these invasive species. Wilderness as a management strategy in forests leads to rather homogenous stands in the short and/or medium term (Beuthler 2001), providing habitats for only a few species. As a result of ongoing management in forests, and as part of wetland restoration, deadwood areas will increase significantly in the coming years. However, in the long term, providing there is enough space undisturbed by humans, a variety of features will emerge in the landscape that will provide a large variety of structures and habitat opportunities for both plants and animals that are dependent on natural dynamics (Scherzinger 1996; Müller et al. 2008; Mönning et al. 2009; Bassler and Muller 2010). Notwithstanding current conservation objectives to designate $2 \%$ wilderness across the country, unmanaged ecosystems will continue to be a rare form of landscape and as such will merit strict protection status.

Smaller amounts of deadwood up to 20 cubic meters per hectare, as can be found in the Serrahn forests, are noted as positive features (Lupp et al. 2011). To promote wider acceptance of these "old growth" features in both the public and sector domain will require efforts in raising awareness and understanding through education and interpretation. The literature suggests there is a correlation between naturalness and positive perception (e.g. Gobster 1999) although it not quite so clear cut in the European context. In the case of the Müritz National Park, it was shown that unmanaged and "wild" impressions are highly appreciated by both visitors and residents, but mainly for those places that had little management before. Abandoned meadows or fields close to lakes as predicted for the coming years have negative impacts on scenic quality. Scenic views will diminish in future.

Urban wastelands without management often seem to be dominated by a few alien invasive species (Kowarik 2005). However, despite invasive species, these areas can still be valuable for conservation, and provide space for biodiversity. That said, negative attitudes towards these patches of urban brownfields and abandoned land prevail because of the association it has with economic decline in the mind of many people. Fallow land does not necessarily need to be seen as negative. Lupp and Konold (2008) demonstrated that for the Müritz study area in north-eastern Germany, which is dominated by large fields, local communities identified fallow land with diminished agriculture, and thus viewed this as a negative attribute. However, a picture showing fallow land was considered interesting and attractive in the picture set assessment. 
The Müritz National Park was perceived as a wilderness since it provides core features associated with wilderness areas, such as tranquillity, naturalness, vast forests, wetlands, bogs and the feeling of solitude. These factors have to be considered in more detail in future. They can be regulated and should be considered more intensively in future planning. Apart from nature conservation, Müritz National Park provides destinations for nature-based tourism and recreation. Looking at predicted trends for tourism in this region (Lupp et al. 2012), the region will benefit from a steady increase in visitor numbers. Important aspects like solitude or the lack of human intervention could be compromised by increased and unregulated tourism development.

\section{REFERENCES}

Bassler C, Muller J (2010) Importance of natural disturbance for recovery of the rare polypore Antrodiella citrinella Niemela and Ryvarden. Fungal Biol 114: 129-133.

Bauer N, Wallner A, Hunziker M (2009) The change of European landscapes: Human-nature relationships, public attitudes towards rewilding, and the implications for landscape management. J Environ Manage 90: 2910-2920.

Beuthler H (2001) Landschaft in neuer Bestimmung: Russische Truppenübungsplätze. Findling, Bliesdorf.

BMU (Federal Ministry for the Environment, Nature Conservation and Nuclear Safety) (2007) National Strategy on Biological Diversity. Berlin.

Breuste J, Breuste I (2001) Stadtnaturschutz - theoretische Positionen und empirische Befunde zur Nutzung und Akzeptanz von Pflegegrün und Wildnatur in der Stadt. Geobotan. Kolloquium, Frankfurt/M. 16: 25-36.

Brouns E (2004) Ist Wildnis planbar? Nat Landsch 79: 57-63.

Gärtner M, Konold W, Richardson DM (2010) Successional changes on a former tank range in eastern Germany: Does increase of the native grass species Molinia caerulea cause decline of less competitive Drosera species? J Nat Conserv 18: 63-74.

Gobster PH, Nassauer JI, Daniel TC, Fry G (2007) The shared landscape: what does aesthetics have to do with ecology? Landscape Ecol 22: 959-973.

Höchtl F, Lehringer S, Konold W (2005) "Wilderness": what it means when it becomes a reality - a case study from the southwestern Alps. Landscape Urban Plan 70: 85-95.

Hohn U, Jürgens C, Otto KH, Prey G, Piniek S, Schmitt T (2007) Industriewälder als Bausteine innovativer Flächenentwicklung in postindustriellen Stadtlandschaften - Ansätze zu einer integrativen wissenschaftlichen Betrachtung am Beispiel des Ruhrgebietes. Conturec 2: 53-67.

Hunziker M (1995) The spontaneous reafforestation in abandoned agricultural lands: perception and aesthetical assessment by locals and tourists. Landscape Urban Plan 31: 399-410.

Hunziker M (2000) Einstellung der Bevölkerung zu möglichen Landschaftsentwicklungen in den Alpen. Eidgenössische Forschungsanstalt WSL, Birmensdorf, Switzerland.

Junghans T (2007) Urban- Industrieelle Flächen als „Hotspots“ der Blütenpflanzen-Vielfalt am Beispiel der Bahn- und Hafenanlagen von Mannheim (Baden-Württemberg). In: Dettmar J, Werner P (eds) Perspektiven und Bedeutung von Stadtnatur für die Stadtentwicklung, Schriftenreihe des Kompetenznetzwerkes Stadtökologie. Darmstadt 2007, pp 87-94.
Keil A (2005) Use and Perception of Post-industrial Urban Landscapes: In: Kowarik I, Körner S (eds) Wild Urban Woodlands. Springer Berlin, Heidelberg, pp 117-130.

Keil P, Sarazin A, Loos GH, Fuchs R (2002) Eine bemerkenswerte industriebegleitende Pteridophyten-Flora in Duisburg, im Randbereich des Naturraumes „Niederrheinisches Tiefland“ Decheniana 155: 5-12.

Kowarik I (2005) Wild urban woodlands: Towards a conceptual framework. In: Kowarik I, Körner S (eds) Wild Urban Woodlands. New perspectives for Urban Forestry. Springer, Berlin, Heidelberg, pp 1-32.

Kowarik I (2008) On the role of alien species in urban flora and vegetation. In: Marzluff J et al. (eds) Urban ecology. An international perspective on the interaction between humans and nature. Springer, New York, pp 321-338.

Lupp G, Heuchele L, Renner C, Pauli P, Siegrist D, Konold W (2012) Outdoor recreation destinations as model regions for adaption to climate change and protecting biodiversity In: Fredman $\mathrm{P}$ et al. (eds) The 6th International Conference on Monitoring and Management of Visitors in Recreational and Protected Areas. Outdoor Recreation in Change Current Knowledge and Future Challenges, Stockholm, Sweden, August 21-24, 2012. Proceedings. Stockholm, 2012, (Forskningsprogrammet Friluftsliv i förändring Rapport; 19), pp 212-213.

Lupp G, Höchtl F, Wende W (2011) "Wilderness" - a designation for Central European landscapes? Landscape Use Policy 28: 594-603.

Lupp G, Konold W (2008) Landscape Preferences and Perception of Both Residents and Tourists. A Case Study in Müritz National Park (Germany). In: Siegrist D, Clivaz C, Hunziker M, Iten S (eds) Visitor Management in Nature-based Tourism - Strategies and Success Factors for Parks and Recreational Areas. HSR Hochschule für Technik, Rapperswil: pp 47-58.

Lupp G, Konold W, Bastian O (in press) Landscape management and landscape changes towards more naturalness and wilderness: Effects on scenic qualities - The case of the Müritz National Park in Germany. J Nat Conserv.

Mathey J, Rink D (2009) Urban Wastelands - a Chance for Biodiversity in Cities? Ecological Aspects, social Perceptions and Acceptance of wilderness by Residents. In: Müller N, Werner P, Kelcey JG (eds) Urban Biodiversity and Design: Implementing the Conversion on Biological Diversity in Towns and Cities. Wiley-Blackwell (Conservation science and practice series), Oxford, pp 406-424.

Moning C, Werth S, Dziock F, Bassler C, Bradtka J, Hothorn T, Muller J (2009) Lichen diversity in temperate montane forests is influenced by forest structure more than climate. Forest Ecol Manage 258: 745-751.

Muller J, Bussler H, Gossner M, Rettetbach T, Duelli P (2008) The European spruce bark beetle Ips typographus in a national park: from pest to keystone species. Biodiv Conserv 17: 2979-3001.

Nationalparkamt Müritz (2003) Nationalparkplan - Leitbild und Ziele. - Hohenzieritz, 150

Nationalparkverwaltung Bayerischer Wald (ed.) (2009) Nationalparkplan - Leitbild und Ziele. http://www.nationalpark -bayerischer-wald.de/doc/service/downloads/nationalparkplan /leitbild_und_ziele_ba_web.pdf. Accessed 20 November 2012.

Okarma H, Langwald D (2002) Der Wolf: Ökologie, Verhalten, Schutz. Parey, Berlin.

Pestel C, Schäfer D (1991) Waldbauliche Behandlungsvorschläge für die Kiefernbestände des Müritz-Nationalparks mit dem Ziel einer Überführung in naturnahe Bestände. Master Thesis, Georg-August-University Universität Göttingen. 
Rink D (2003) Ist wild schön? Untersuchung zur Akzeptanz von Sukzession in der Stadt. Garten+Landschaft, 2/2004: 16-18.

Schemel HJ, Reidl K, Blinkert B (2005) Naturerfahrungsräume im besiedelten Bereich. Nat schutz Landsch plan 37: $5-14$.

Scherzinger W (1996) Naturschutz im Wald. Qualitätsziele einer dynamischen Waldentwicklung. Reihe Praktischer Naturschutz. Stuttgart-Hohenheim.

Stremlow M, Sidler C (2002) Schreibzüge durch die Wildnis. Wildnisvorstellungen in Literatur und Printmedien der Schweiz.
Bristol-Stiftung, Zürich; Eidgenössische Forschungsanstalt WSL, Birmensdorf; Haupt, Bern, Stuttgart, Wien.

UBA (Ed.) (2009) Umweltbewusstsein und Umweltverhalten der sozialen Milieus in Deutschland. Dessau-Roßlau.

Vincenzotti V, Trepl L (2009) City as Wilderness: The Wilderness Metaphor from Wilhelm Heinrich Riehl to Contemporary Urban Designers. Landscape Res 34: 380-396.

Wasem K (2002) Akzeptanz von Wildnisgebieten. Hintergründe zur Befürwortung und Ablehnung von Wildnisgebieten dargestellt an den Fallbeispielen Naturlandschaft Sihlwald und Auenschutzpark Aargau, Geogr Inst Univ Zürich. 